\title{
Creating A Model For Graduate Student Inclusion And Success
}

\author{
Irene M. Duranczyk, University of Minnesota, Twin Cities, USA \\ Jennifer Franko, University of Minnesota, Twin Cities, USA \\ Shade' Osifuye, University of Minnesota, Twin Cities, USA \\ Amy Barton, University of Minnesota, Twin Cities, USA \\ Jeanne L. Higbee, University of Minnesota, Twin Cities, USA
}

\begin{abstract}
Mentoring and advising are critical aspects of the graduate student experience, and can have a significant impact on the professional lives of future postsecondary faculty and staff and a rippling effect throughout higher education and the global economy. This paper describes the process a new department undertook to create a graduate program that puts the inclusion and success of students first.
\end{abstract}

Keywords: Graduate Students; Mentoring; Advising; Student Professional Development; Multicultural Education; Inclusion

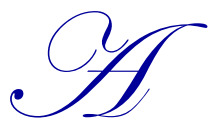

recent report from the Commission on Pathways Through Graduate School and Into Careers (Council of Graduate Schools \& Educational Testing Service, 2012) asserted the importance of graduate education to the health of the US economy. "To ensure that a diverse, talented workforce supports the future success of the U.S. economy and society, we must understand current pathways through graduate school into careers as well as emerging employment trends and opportunities" (Wendler, Bridgeman, Markle, Cline, Bell, McAllister, \& Kent, 2012, p. 2). Many other nations also send some of their brightest students and future leaders to the US for graduate school. In fact, a brief from the National Foundation for American Policy (Anderson, 2013) indicated that there are more international students than US citizens in many US science, technology, engineering, and mathematics (STEM) graduate programs, with $70.3 \%$ of electrical engineering students, $63.2 \%$ of computer science students, and $55.4 \%$ of economics majors coming from other nations. Although not the majority, more than $40 \%$ of mathematics, statistics, chemistry, and physics graduate students enrolled in US institutions are international students. Thus, the nature of the graduate school experience in the US has global implications.

Most postsecondary faculty have heard anecdotes about the experiences of graduate students - both good and bad. Mentoring and advising are critical aspects of the graduate student experience, and can have a significant impact on the professional lives of future postsecondary faculty and staff, as well as leaders across all fields, at the global level. The Pathways report noted, "Responses to our survey confirmed the importance of faculty in student career development, with most students indicating that a faculty member or advisor primarily provided career advice, far more than any other group of influencers" (Wendler et al., 2012, p. 3). Thus, it is imperative that graduate faculty understand the importance of their role and pay closer attention to the nature of the interactions they have with students both within and outside the classroom. This paper describes the process a new department undertook to create a graduate program that puts the inclusion and success of students first. Although this particular program is within the College of Education and Human Development (CEHD) at the University of Minnesota, graduate students from across the University participate in its courses and programs, including its postbaccalaureate certificate in Innovations in Undergraduate Multicultural Teaching and Learning, which is designed to assist doctoral students and others in developing teaching and academic support strategies to serve diverse populations of learners. 


\section{BACKGROUND}

In 2006 the University of Minnesota, Twin Cities, closed the General College (GC), a 74-year-old experiment in providing an inclusive and supportive learning environment for promising undergraduate students at the University who might otherwise have been denied admission based on standard measures like test scores and high school class rank (Higbee, Lundell, \& Arendale, 2005). Many of GC's multidisciplinary faculty and academic staff members were retained in a new department, Postsecondary Teaching and Learning (PsTL), which was moved to CEHD. CEHD became a freshman-admitting college and PsTL was charged with creating a first-year program and related courses for the newly-expanded college. The PsTL faculty were also asked to develop graduate programs that would utilize the talents of this diverse group, who had degrees in fields like physics, law, sociology, biology, psychology, geology, mathematics, anthropology, literature, history, and so on. The outcome of this process was the launching of a new Master of Arts program in Multicultural College Teaching and Learning, as well as the postbaccalaureate certificate. Courses in CEHD's new first-year curriculum could then serve as laboratories for research and practice for PsTL faculty and graduate students.

PsTL began by exploring departmental values and mission. The PsTL motto is "You Belong Here!" The values statement agreed upon by PsTL faculty and staff reads as follows:

The Department of Postsecondary Teaching and Learning is committed to the core values of social justice, equity, inclusion, and mutual respect. In our research, teaching, and community engagement activities, we seek to enact these values by fostering open communication and collaboration; facilitating development of reflective, creative, and critical thinking and problem-solving skills; considering and utilizing multicultural and global perspectives; valuing multiple means of demonstrating and assessing knowledge; and promoting engaged citizenship.

In alignment with its new charge and statement of values, PsTL adopted the following mission statement:

The mission of the Department of Postsecondary Teaching and Learning is to provide student-centered, multicultural, multidisciplinary learning opportunities for a diverse population of students, faculty, and staff; conduct research related to postsecondary pedagogy, student development, learning outcomes, access, and success; and develop engaged partnerships with communities, organizations, and programs so as to support access to and success in higher education.

These statements then served as the foundation that guided the development of all PsTL programs, including the new MA and certificate:

In Minnesota and beyond, postsecondary educators face the challenge of increasing persistence, supporting engaged learning, and promoting success to graduation, particularly for traditionally underrepresented student populations. The mission for PsTL graduate programs is to contribute comprehensive solutions to improve the quality of teaching and learning for all undergraduates by focusing on the changing faces of postsecondary education in the U.S. and equipping educators and educational policymakers to ensure the success of an increasingly diverse population of students and citizens. Our programs are designed to meet the need for 21 st century graduate programming in postsecondary teaching and learning to address contemporary local, state, and national contexts in community colleges and 4-year institutions. PsTL graduate programs serve current and future faculty and staff at undergraduate institutions who are interested in developing innovative teaching and learning strategies with an emphasis on access and success for diverse student populations (Department of Postsecondary Teaching and Learning, 2011, p. 7).

\section{CREATING A CULTURE OF INCLUSION}

Prior to and during the transition from a college to a department, GC faculty, staff, and students engaged in an extensive series of projects to explore college climate and inclusion for a diverse population of students (Barron, Pieper, Lee, Nantharath, Higbee, \& Schultz, 2007; Bruch \& Higbee, 2002; Bruch, Higbee, Jehangir, \& Siaka, 2004; Bruch, Higbee, \& Siaka, 2007; Bruch, Jehangir, Lundell, Higbee, \& Miksch, 2005; Clinton \& Higbee, 2011; Ghere, 
Kampsen, Duranczyk, \& Christensen, 2007; Higbee, 2009; Higbee \& Barajas, 2007; Higbee, Bruch, \& Siaka, 2008; Higbee, Duranczyk, \& Ghere, 2008; Higbee \& Goff, 2008; Higbee et al., 2005; Higbee, Lundell, \& Duranczyk, 2003, 2008; Higbee, Miksch, Jehangir, Lundell, Bruch, \& Jiang, 2004; Higbee \& Siaka, 2005; Higbee, Siaka, \& Bruch, 2007a, 2007b; Jehangir, 2008, 2009; Jehangir, Yamasaki, Ghere, Hugg, Williams, \& Higbee, 2002; Miksch, Higbee, Jehangir, Lundell, Bruch, Siaka, \& Dotson, 2003). These efforts eventually led to the development and assessment of a new pedagogical model for integrated multicultural instructional design (Higbee \& Goff, 2015). The members of the PsTL Graduate Faculty challenged themselves to apply these research findings to practice within the curriculum of the new MA program and the contents of its courses as well as in modeling inclusive pedagogy in their teaching and advising. Recent reports from the University of Minnesota's Student Conflict Resolution Center (SCRC; 2007, 2011) exposed alarming acts of incivility toward graduate students across the institution. The SCRC (2010) also provided guidance for implementing best practices in advising and mentoring graduate students. PsTL aimed to be a leader in establishing policies and procedures to ensure graduate student inclusion and success.

One of the first decisions in designing the new MA program was to use a cohort model and to take specific steps to ensure a sense of community within and between annual cohorts. Each August PsTL has hosted an orientation dinner for new students that gives them the opportunity to interact informally with faculty and returning students, while also providing a venue for reviewing policies and procedures, acquainting students with campus resources, and making them aware of professional development opportunities on campus and through local and national professional organizations. Faculty briefly share their research interests and introduce the courses they teach. Other events are held throughout the year, and the students have also created a monthly electronic newsletter that includes feature articles about individual students and alumni as well as photographs, announcements, tips, and events. The newsletter became so popular that faculty and staff asked to be added to the circulation list.

Another critical decision was to exclude Graduate Record Examination (GRE) scores from the admissions process. Undergraduate cumulative grade point averages (GPAs), although required by the University, are also given less importance than in most graduate programs. Instead, the focus is on the students' personal statements about their experiences and goals, what they hope to learn, and contributions they can make to the program. The students come from a wide range of backgrounds, and both faculty and students frequently comment on how much we learn from one another both within and outside the classroom. Our goal of inclusion and success for all students in the program continues to be our highest priority.

We are very pleased with our efforts to recruit, admit, and retain a highly diverse population of MA students. The first cohort was very small, but those students have proven to be a significant asset in recruiting others. Out of 36 current MA students and recent alumni, $22(61.1 \%)$ are female. The minimum age at point of admission is 22 , the maximum is 58 , and the mean is 32.9 years old. Six participants in the MA program have come from other countries - two from China and one each from Colombia, Spain, India, and Panama. White students make up only $38.9 \%$ of the group. One student is American Indian (2.8\%), five are Hispanic (13.9\%), seven are Asian (19.4\%), and nine are Black $(25.0 \%)$. It should be noted that although the University reports data using census terminology for race and ethnicity, among the group there are students who immigrated from Southeast Asia and East Africa, several of whom came to the U.S. after extended periods in refugee camps. These are students whose life experiences and potential for success cannot necessarily be captured by high school GPA and standardized test scores.

\section{ADVISING}

The PsTL Graduate Faculty voted unanimously to adopt a policy that required advisers to meet with each advisee at least twice per semester. The primary responsibilities of advisers listed in the policy are as follow:

- Assist the student in formulating a program of study and research that culminates in the timely completion of the degree.

- Meet with the student to complete the annual review of the student's progress and submit the annual review form to the PsTL director of graduate studies (DGS).

- Review and attach a recommendation to any petition the student may make with respect to graduate status, requesting acceptance of an elective from another institution, leave of absence, etc. 
- Direct the student's research for and writing of the Plan A thesis or development and completion of the Plan B capstone project.

- $\quad$ Serve as chair of the student's examination committee.

Additional responsibilities deemed important by the PsTL Graduate Faculty included the following:

- Inform the student about appropriate opportunities related to

- professional development.

$\circ \quad$ membership in professional organizations.

$\circ \quad$ career and employment.

$\circ \quad$ networking.

- publications.

- $\quad$ Assist the student in navigating University resources such as financial aid, health services, housing and leadership opportunities.

- $\quad$ Serve as a professional reference for employment, scholarship and fellowship applications, and other opportunities.

Advisers are responsible for facilitating their advisees' progress toward degree completion. PsTL has designed an annual review process as a way to support students' professional development and achievement of academic, career, and life goals. This annual review recognizes students' achievements while also ensuring that any concerns are identified early so that students receive timely guidance when appropriate. Each spring semester all PsTL MA students are required to meet with their adviser to discuss progress toward degree. The student and the adviser collaborate to complete the PsTL MA Student Annual Review Form, which includes student accomplishments for the past year, goals for the coming year, and concerns for the coming year, which may reflect individual challenges, institutional barriers, or any other areas of concern that need to be addressed to facilitate timely completion of the MA degree. The results of this review are forwarded to the DGS, who consults with the Graduate Advisory Committee (GAC) and the DGS Assistant (DGSA). The GAC determines whether each student is making adequate progress toward degree completion and the DGS provides every student with a letter indicating the GAC decision. Any student who is not making adequate progress toward the MA degree will be afforded an opportunity to demonstrate that these concerns can be addressed and that degree completion is likely. Although an annual review is required for all graduate students at the University of Minnesota, Twin Cities, the results of these reviews often come as a surprise to the students, whose involvement in many departments is limited to receiving a letter from the DGS stating whether or not the student is making adequate progress and whether the student's continuation in the program for the coming academic year is approved or the student has been dismissed from the program. The PsTL process is not only far more collegial, informative, and humane; it also provides the department with metrics data related to student presentations, publications, fellowships, scholarships, other honors, assistantships, and other employment.

Following the annual review of MA student progress each spring, PsTL administers an advising survey to all MA students to determine whether the services outlined in the policy are being provided and goals for the advising process are being met. This article reports on data from the 2012-2013academic year. The mean number of appointments each student had with their primary adviser was 3.1 for fall semester and 3.4 for spring. Table 1 provides the mean results for the other items from the evaluation of advising on a Likert-type scale $(1=$ strongly disagree, 4 = strongly agree). 
Table 1. Summary of Graduate Students' Perceptions of MA Advising, Fall 2012 (Advising Survey)

\begin{tabular}{|c|c|c|c|c|c|}
\hline Survey Questions & n & $\begin{array}{c}\text { Minimum } \\
\text { Rating }\end{array}$ & $\begin{array}{c}\text { Maximum } \\
\text { Rating }\end{array}$ & $\mathbf{M}$ & SD \\
\hline My adviser is available when needed. & 11 & 2 & 4 & 3.36 & 674 \\
\hline $\begin{array}{l}\text { My adviser has a thorough understanding of the program } \\
\text { requirements. }\end{array}$ & 11 & 2 & 4 & 3.55 & .688 \\
\hline $\begin{array}{l}\text { My adviser has a thorough understanding of my overall } \\
\text { progress. }\end{array}$ & 11 & 3 & 4 & 3.64 & .505 \\
\hline Meetings with my adviser are productive. & 11 & 3 & 4 & 3.82 & .405 \\
\hline My adviser listens to my concerns and questions. & 11 & 3 & 4 & 3.91 & .302 \\
\hline My adviser provides constructive feedback. & 11 & 3 & 4 & 3.82 & .405 \\
\hline $\begin{array}{l}\text { My adviser provides useful guidance in the development of } \\
\text { my Plan A Master's Thesis or my Plan B Capstone Project. }\end{array}$ & 11 & 3 & 4 & 3.82 & .405 \\
\hline $\begin{array}{l}\text { How useful to you was the orientation session at the } \\
\text { beginning of Fall semester? }\end{array}$ & 9 & 3 & 4 & 3.56 & .527 \\
\hline Overall, how satisfied are you with the PsTL MA program? & 11 & 3 & 4 & 3.73 & .467 \\
\hline
\end{tabular}

\section{STUDENT PROFESSIONAL DEVELOPMENT}

PsTL faculty have embraced the notion that "Universities, graduate leaders, and faculty are on the front line of preparing the workforce of the future" (Wendler et al., 2012, p. 4), and have thus endeavored to provide additional professional development opportunities for all students in the MA and certificate programs, as well as graduate students minoring in the department or taking individual courses. The MA program requires a 100 -hour practicum experience, as well as 3 to 6 credits of internship, with each credit representing 45 hours of work (i.e., 3 hours per week for the 15 -week semester) at the internship site.

The Pathways report recommended the following priorities for universities and their faculty:

- $\quad$ Make connections with students.

- $\quad$ Track career outcomes and job placement information for graduate students.

- $\quad$ Connect graduate students with graduate alumni.

- $\quad$ Broaden the focus of graduate education to include development of professional skills. (Wendler et al., 2012, p. 4)

To initiate connections between faculty and students and expand the focus on professional skills, the PsTL GAC Assessment Subcommittee created a survey to be administered to PsTL graduate students each fall to determine their priorities for the advising experience on scale of 1 (not at all important) to 4 (very important). The instrument is provided as the appendix to this paper. Students' highest priority $(M=3.7, S D=0.95)$ was the Plan A thesis or Plan B capstone project, a requirement for graduation. Although the thesis can be a key experience for students who intend to pursue a doctorate at some point in the future ( $80 \%$ of PsTL MA students), many choose to do a capstone project that is more applied and provides additional professional preparation and experience. Some students have designed courses or programs (e.g., an orientation program specifically for international students majoring in business) for the capstone, while others have used it as an opportunity to apply theory to practice in their current employment (e.g., McDowell \& Higbee, 2014) or conduct research with a more applied report as the final product rather than a thesis (e.g., Osifuye \& Higbee, 2014). The next highest priority was discussing career goals $(M$ $=3.5, S D=0.97)$. Workshops and other activities of interest that were prioritized by the students included writing in American Psychological Association (APA) style, developing a professional curriculum vitae, applying and interviewing for jobs, and developing conference proposals. PsTL graduate faculty members then developed these ideas into workshops that were presented monthly in conjunction with one of several evening course offerings. Class would meet as regularly scheduled for the first hour, followed by free dinner and the workshop, which any graduate student or alumnus in some way affiliated with PsTL could attend. The dinner portion of the event provided opportunities for more casual conversation among the students, alumni, and faculty. 
Students also expressed interest in participating in professional organizations and their conferences. PsTL created a fund to support these activities in memory of a colleague, the David Ghere Fund for Student Professional Development. With support from friends and family, that fund has now been endowed. For the past 3 years, graduate students have applied for support to finance attending and presenting sessions at state, national, and international conferences hosted in Minnesota.

Tracking outcomes is also important in PsTL. Each summer the DGSA conducts exit interviews with recent graduates. Interview items ask students to comment on:

- $\quad$ Extent to which the program helped student achieve academic and career goals

- $\quad$ Research interests (now and during program)

- $\quad$ Publications and conference presentations developed

- $\quad$ Awards, grants, fellowships received

- $\quad$ Extent to which expectations were met

- $\quad$ Post-graduate plans (including whether employed and a description of that work, if applicable)

We are pleased to report that all alumni of the MA program have found meaningful employment related to the degree and/or started a doctoral program. Figure 1 provides examples of job placements for recent alumni.

Figure 1. MA Program Recent Alumni (Fall 2011 \& 2012 Cohorts) Employers and Position Titles

\begin{tabular}{|l|l|}
\hline \multicolumn{1}{|c|}{ Employer } & \multicolumn{1}{|c|}{ Title } \\
\hline Universidad Pontificia Bolivariana, Colombia & Associate Professor \& Researcher \\
\hline Minneapolis Community and Technical College & $\begin{array}{l}\text { Recruitment and Retention Advisor for Career and Technical } \\
\text { Education }\end{array}$ \\
\hline $\begin{array}{l}\text { Minnesota's Future Doctors Program, University of } \\
\text { Minnesota }\end{array}$ & Program Director \\
\hline Spanish Institute of Minnesota & Spanish Language Instructor \\
\hline Mobile (AL) County Public School System & 7th Grade Math Teacher \\
\hline University of Minnesota Extension & Academic Technologist \\
\hline Student Unions, University of Minnesota & Coordinator \\
\hline $\begin{array}{l}\text { Minneapolis Community and Technical College TRIO } \\
\text { Programs }\end{array}$ & Program Adviser \\
\hline CEHD Student Services, TRIO McNair Scholars Program & Assistant Academic Adviser \\
\hline University of Wisconsin-Oshkosh & Transfer Admissions Counselor \\
\hline Capella University & Doctoral Academic Advisor \\
\hline $\begin{array}{l}\text { Academic Technology Support Services - University of } \\
\text { Minnesota, Twin Cities }\end{array}$ & Instructional Designer \\
\hline Hampshire College (MA) & Chinese Language Instructor \\
\hline University of Wisconsin-Stout, & $\begin{array}{l}\text { Multicultural Recruitment \& Retention Coordinator / Director of } \\
\text { TEACH Support Network }\end{array}$ \\
\hline
\end{tabular}

\section{CONCLUSION}

The purpose of this paper has been to articulate how a department can take a very intentional approach to ensuring inclusion and success for its graduate students. We have also discussed a four-prong approach to assessing our efforts: (a) the advising priorities survey, (b) the process for the annual review of MA student progress, (c) the advising evaluation, and (d) the exit interview. We hope that this information will be useful to other programs that are concerned with eliminating incivility toward graduate students, enhancing the graduate-level advising and mentoring processes, promoting degree completion, preparing students for life after graduate school, and creating a network of allies for graduate students and alumni from diverse and historically underserved populations.

We conclude each year with a commencement dinner provided free of charge by the department at a beautiful facility on campus. Students who are graduating invite significant others. All graduate program current and incoming students and alumni (MA, certificate, and minors) are invited, as well as faculty and staff. This event saves graduating students and their families the expense of hosting a meal that includes the graduate adviser, is 
convenient, and provides everyone with an opportunity to network. It is an elegant event that is very well attended. At the 2014 dinner a recently-admitted student who had just completed a master's degree in another department and would not begin PsTL classes until fall shared, "In this one evening PsTL has made me feel more welcome here than I ever have throughout my undergraduate and previous graduate student experiences. You truly do mean it when you say, 'You belong here!"’

\section{AUTHOR INFORMATION}

Irene M. Duranczyk is an Associate Professor at the University of Minnesota in the Department of Postsecondary Teaching and Learning in the College of Education and Human Development (CEHD) and currently teaches and advises students in the PsTL postbaccalaureate certificate and MA programs. She earned her B.A. in Chemistry at Oakland University, M.Ed. in Educational Leadership at Wayne State University, and Ed.D. in Higher Education Administration and Management at Grambling State University. Irene was a member of the PsTL GAC and chair of the Recruitment and Professional Development subcommittee (2012-2014). Irene received the CEHD Multicultural Recognition Faculty Award in 2013. Irene has presented and published numerous papers on mentoring graduate students and advancing multicultural education and opportunities for graduate students. E-mail: duran026@umn.edu (Contact author)

Jennifer Franko earned her B.S. in Kinesiology and MA in Therapeutic Recreation. When presented with an opportunity to pursue program evaluation, she obtained her Program Evaluation Postbaccalaureate Certificate in 2007. Since then she has been the primary PsTL departmental resource for institutional research and formative and summative program assessment. She assumed DGSA responsibilities in 2010 and has supported faculty and students in all PsTL graduate programs since their inception. E-mail: frank010@umn.edu

Shade' Osifuye completed a Master's degree in Multicultural College Teaching and Learning in the College of Education and Human Development at the University of Minnesota. She is a TRIO McNair Scholars Alumna and a TRIO McNair Academic Advisor for the Ronald E. McNair Undergraduate Summer Research Program. After completing her Bachelors of Arts degree she lived in Kenya, volunteering at a center for children with disabilities, working with students with disabilities, teaching English to children in slum environments, and working in an HIV/AIDS clinic - all of which had a profound impact on her life and resulted in her decision to focus on serving people with disabilities and their families locally and globally. E-mail: osif0003@umn.edu

Amy Barton received her Bachelor of Science degree in Family Social Science from the University of Minnesota. She worked in nonprofit and corporate industries before returning to graduate school. She will be graduating in May 2015 with a Master of Arts in Multicultural College Teaching and Learning. She co-conducted an action research project that focused on the career development needs of TRIO students which influenced her own research interests. Her research area for her capstone is how student services practitioners can utilize a values-based approach with students who are exploring major/career options. Amy has worked in various roles as a graduate student conducting research; career counseling with undergraduates, graduates and alumni; and academic advising with premed students. This year she received the Carol E. Macpherson Scholarship which is dedicated to assisting women in achieving their educational goals and dreams. Amy is also on the Alumni Society Board which provides various ways for graduating seniors and alumni to engage with the University. E-mail: fjel0032@umn.edu

Jeanne L. Higbee earned her B.S. in Sociology from Iowa State University and her M.S. in Counseling and Ph.D. in Educational Administration/Higher Education from the University of Wisconsin-Madison. She recently retired from her faculty position at the University of Minnesota, Twin Cities, where from 2011 to 2014 she served as Director of Graduate Studies for the MA in Multicultural College Teaching and Learning. In 2011 she received the University of Minnesota's prestigious Horace T. Morse-University of Minnesota Alumni Association Award for Outstanding Contributions to Undergraduate Education. She is an ACPA-College Student Educators International Diamond Honoree and the recipient of the ACPA Voice of Inclusion Medallion and Disability Ally Award, the College Reading and Learning Association (CRLA) Robert Griffin Award for Long and Outstanding Service, the Henry Young Award for Outstanding Individual Contribution to the National Association for Developmental Education (NADE), and NADE's Hunter R. Boylan Outstanding Research/Publication Award. E-mail: higbe002@umn.edu 


\section{REFERENCES}

Anderson, S. (2013). The importance of international students to America. Arlington, VA: National Foundation for American Policy. Retrieved from

http://www.nfap.com/pdf/New\%20NFAP\%20Policy\%20Brief\%20The\%20Importance\%20of\%20International\% 20Students\%20to\%20America,\%20July\%202013.pdf

Barron, R., Pieper, J., Lee, T., Nantharath, P., Higbee, J. L., \& Schultz, J. (2007). Diversity and the postsecondary experience: Students give voice to their perspectives. In J. L. Higbee, D. B. Lundell, \& I. M. Duranczyk (Eds.), Diversity and the postsecondary experience (pp. 37-47). Minneapolis, MN: University of Minnesota, Center for Research on Developmental Education and Urban Literacy. Retrieved from http://www.cehd.umn.edu/CRDEUL/docs/monograph/Diversity.pdf

Bruch, P. L., \& Higbee, J. L. (2002). Reflections on multiculturalism in developmental education. Journal of College Reading and Learning, 33(1), 77-90.

Bruch, P. L., Higbee, J. L., Jehangir, R., \& Siaka, K. (2004). Changing the talk we walk: The multicultural awareness project for institutional transformation (MAP IT). Proceedings of Keeping Our Faculties III Conference: Recruiting, retaining, and advancing faculty of color. Minneapolis, MN: University of Minnesota.

Bruch, P. L., Higbee, J. L., \& Siaka, K. (2007). Multiculturalism, Incorporated: Student perspectives. Innovative Higher Education, 32, 139-152.

Bruch, P. L., Jehangir, R. R., Lundell, D. B., Higbee, J. L., \& Miksch, K. L. (2005). Communicating across differences: Toward a multicultural approach to institutional transformation. Innovative Higher Education, 29, 195-208.

Clinton, L., \& Higbee, J. L. (2011). The invisible hand: The power of language in creating welcoming postsecondary learning experiences. Journal of College Teaching and Learning, 8(5), 11-16.

Council of Graduate Schools and Educational Testing Service. (2012). Pathways through graduate school and into careers. Report from the Commission on Pathways Through Graduate School and Into Careers. Princeton, NJ: Educational Testing Service. Retrieved from www.pathwaysreport.org

Department of Postsecondary Teaching and Learning. (2011). Graduate student handbook. Minneapolis, MN: Author.

Ghere, D. L., Kampsen, A., Duranczyk, I., \& Christensen, L. L. (2007). Adopting and integrating multiculturalism: A closing assessment of General College. In J. L. Higbee, D. B. Lundell, \& I. M. Duranczyk (Eds.), Diversity and the postsecondary experience (pp. 25-36). Minneapolis, MN: University of Minnesota, Center for Research on Developmental Education and Urban Literacy. Retrieved from http://cehd.umn.edu/CRDEUL/docs/monograph/Diversity.pdf

Higbee, J. L. (2009). Student diversity. In R. Flippo \& D. Caverly (Eds.), Handbook of college reading and study strategies research ( $2^{\text {nd }}$ ed.; pp. 67-94). New York, NY: Routledge, Taylor \& Francis Group.

Higbee, J. L., \& Barajas, H. L. (2007). Building effective places for multicultural learning. About Campus, 12(3), 16-22.

Higbee, J. L., Bruch, P. L., \& Siaka, K. (2008). Disability and diversity: Results from the multicultural awareness project for institutional transformation. In J. L. Higbee \& E. Goff (Eds.), Pedagogy and student services for institutional transformation: Implementing universal design in higher education (pp. 405-417). Minneapolis, MN: University of Minnesota, Center for Research on Developmental Education and Urban Literacy. Retrieved April 8, 2009, from http://cehd.umn.edu/passit/docs/PASS-IT-Book.pdf

Higbee, J. L., Duranczyk, I. M., \& Ghere, D. (2008). Institutional transformation: From multicultural awareness to integrated multicultural instructional design. In F. Ferrier \& M. Heagney (Eds.), Higher education in diverse communities: Global perspectives, local initiatives (pp. 60-65). London, UK: European Access Network and Higher Education Authority of Ireland.

Higbee, J. L., \& Goff, E. (2008). Pedagogy and student services for institutional transformation: Implementing universal design in higher education. Minneapolis, MN: University of Minnesota, Center for Research on Developmental Education and Urban Literacy. Retrieved from http://www.cehd.umn.edu/passit/docs/PASS-IT-Book.pdf

Higbee, J. L., Lundell, D. B., \& Arendale, D. R. (Eds.). (2005). The General College vision: Integrating intellectual growth, multicultural perspectives, and student development. Minneapolis, MN: University of Minnesota, General College, Center for Research on Developmental Education and Urban Literacy. Retrieved from http://www.cehd.umn.edu/CRDEUL/books-thegcvision.html

Higbee, J. L., Lundell, D. B., \& Duranczyk, I. M. (Eds.). (2003). Multiculturalism in developmental education. Minneapolis, MN: University of Minnesota, General College, Center for Research on Developmental Education and Urban Literacy. Retrieved from http://www.cehd.umn.edu/CRDEUL/pdf/monograph/4-a.pdf

Higbee, J. L., Lundell, D. B., \& Duranczyk, I. M. (Eds.). (2007). Diversity and the postsecondary experience. Minneapolis, MN: University of Minnesota, Center for Research on Developmental Education and Urban Literacy. Retrieved from http://www.cehd.umn.edu/CRDEUL/docs/monograph/Diversity.pdf 
Higbee, J. L., Miksch, K. L., Jehangir, R. R., Lundell, D. B., Bruch, P. L., \& Jiang, F. (2004/2007). Assessing our commitment to providing a multicultural learning experience. Journal of College Reading and Learning, 34(2), 61-74. Reprinted in J. L. Higbee, L. MacDonald, D. Van Blerkom, E. Miller Payne, \& R. Smilkstein (Eds.), Best practices in college reading and learning: In memory of Cynthia L. Peterson (pp. 125-139). El Dorado, KS: College Reading and Learning Association.

Higbee, J. L., \& Siaka, K. (2005). Students' assessment of their multicultural experiences in the General College: A pilot study. In J. L. Higbee, D. B. Lundell, \& D. R. Arendale (Eds.), The General College vision: Integrating intellectual growth, multicultural perspectives, and student development. Minneapolis, MN: University of Minnesota, General College, Center for Research on Developmental Education and Urban Literacy. Retrieved from http://cehd.umn.edu/CRDEUL/books-thegcvision.html

Higbee, J. L., Siaka, K., \& Bruch, P. L. (2007a). Assessing our commitment to multiculturalism: Student perspectives. Journal of College Reading and Learning, 37(2), 7-25.

Higbee, J. L., Siaka, K., \& Bruch, P. L. (2007b). Student perceptions of their multicultural learning environment: A closer look. In J. L. Higbee, D. B. Lundell, \& I. M. Duranczyk (Eds.), Diversity and the postsecondary experience (pp. 3-23). Minneapolis, MN: University of Minnesota, Center for Research on Developmental Education and Urban Literacy. Retrieved from http://cehd.umn.edu/CRDEUL/docs/monograph/Diversity.pdf

Jehangir, R. (2008). In their own words: Voices of first generation students in a multicultural learning community. Opportunity Matters, 1(1), 22-31.

Jehangir, R. (2009). Cultivating voice: First generation students seek full academic citizenship in multicultural learning communities. Innovative Higher Education. 34(1), 33-49.

Jehangir, R., Yamasaki, M., Ghere, D., Hugg, N., Williams, L. A., \& Higbee, J. L. (2002). Creating welcoming spaces. Symposium proceedings: Keeping our faculties: Addressing the recruitment and retention of faculty of color, 99101 .

McDowell, A. M., \& Higbee, J. L. (2014). Responding to the concerns of student cultural groups: Redesigning spaces for cultural centers. Contemporary Issues in Education Research, 7(3), 227-236.

Miksch, K. L., Higbee, J. L., Jehangir, R. R., Lundell, D. B., Bruch, P. L., Siaka, K., \& Dotson, M. V. (2003). Multicultural Awareness Project for Institutional Transformation: MAP IT. Minneapolis, MN: University of Minnesota, General College, Multicultural Concerns Committee and Center for Research on Developmental Education and Urban Literacy. Retrieved from http://www.cehd.umn.edu/CRDEUL/pdf/map_it.pdf

Osifuye, S., \& Higbee, J. L. (2014). African university students' perspectives on disability access. Journal of Diversity Management. 9(2), 1-10.

University of Minnesota Student Conflict Resolution Center. (2007). Academic incivility and the graduate student experience: Summary of fall 2007 survey of UMN-TC graduate students. Minneapolis, MN: Author. Retrieved from http://www.sos.umn.edu/stafffaculty/Survey_Summary_AcadInc_UMNTC.pdf

University of Minnesota Student Conflict Resolution Center. (2010). Graduate student adviser evaluation. Strategies for improving advising and mentoring of graduate and professional students (p. 4). Minneapolis, MN: Author. Retrieved from http://www.sos.umn.edu/stafffaculty/Strategies-Orientation\%20Planing\%20Guide.pdf

University of Minnesota Student Conflict Resolution Center. (2011). Academic incivility and the graduate student experience: Summary of spring 2011 survey of UMN-TC graduate and professional students. Minneapolis, MN: Author. Retrieved from http://www.sos.umn.edu/stafffaculty/Survey\%20Summary\%202011\%20\%28revised\%208-12-11\%29.pdf

Wendler, C., Bridgeman, B., Markle, R., Cline, F., Bell, N., McAllister, P., \& Kent, J. (2012). Pathways through graduate school and into careers. Executive summary. Princeton, NJ: Educational Testing Service and Council of Graduate Schools, The Commission on Pathways Through Graduate School and Into Careers. Retrieved from www.pathwaysreport.org 


\section{APPENDIX: PsTL MA Student Advising Priorities Survey}

Thank you for completing this anonymous survey, which will be used to guide advising policies and procedures in PsTL, assess interest in topics for future professional development workshops for both students and faculty, and provide ideas for next year's PsTL Graduate Student Handbook.

\section{Advising Priorities}

On a scale of 1 to 4 , where $1=$ not at all important and $4=$ very important, please rate each of the following advising topics in terms of its importance to you personally:

$\begin{array}{lllll}1 & 2 & 3 & 4 & \text { Career goals } \\ 1 & 2 & 3 & 4 & \text { Course and program planning and decision making } \\ 1 & 2 & 3 & 4 & \text { Progress toward degree } \\ 1 & 2 & 3 & 4 & \text { Campus resources } \\ 1 & 2 & 3 & 4 & \text { Completing necessary forms } \\ 1 & 2 & 3 & 4 & \text { Progress in individual courses } \\ 1 & 2 & 3 & 4 & \text { Plan A thesis or Plan B capstone project } \\ 1 & 2 & 3 & 4 & \text { Assistantship and/or fellowship opportunities } \\ 1 & 2 & 3 & 4 & \text { Professional organizations } \\ 1 & 2 & 3 & 4 & \text { Opportunities to attend professional conferences } \\ 1 & 2 & 3 & 4 & \text { Opportunities to present at professional conferences } \\ 1 & 2 & 3 & 4 & \text { Networking opportunities } \\ 1 & 2 & 3 & 4 & \text { Research opportunities } \\ 1 & 2 & 3 & 4 & \text { Publication opportunities } \\ 1 & 2 & 3 & 4 & \text { Job search } \\ 1 & 2 & 3 & 4 & \text { Serving as a professional reference } \\ 1 & 2 & 3 & 4 & \text { Individual challenges and/or concerns } \\ 1 & 2 & 3 & 4 & \text { Other: Please explain }\end{array}$

\section{Activities of Interest}

Please check which of the following activities you would be interested in pursuing with your adviser or another PsTL Graduate Faculty member:

Developing a professional vita

Developing a local professional network of colleagues for support \& collaboration

Developing a national professional network of colleagues for support \& collaboration

Learning about how to become involved in professional associations

Learning about leadership opportunities in professional associations

— Learning about becoming involved in editorial responsibilities (e.g., serving on an editorial board) in professional associations

Developing ideas for professional presentations

Co-presenting at a local conference

Participating at a local conference, but not presenting

Co-presenting at a national conference

Participating at a national conference, but not presenting

Transforming the Plan A thesis or Plan B capstone project into a professional presentation

_ Transforming the Plan A thesis or Plan B capstone project into a professional publication

Developing other ideas for professional publications

Co-authoring a professional publication

Becoming involved in a research project

Becoming involved in a grant proposal

Other: Please explain: 


\section{Workshops of Interest}

Please check indicate whether you would be interested in participating in a professional development workshop (late afternoon/ early evening with dinner provided) next semester (SP 2013) on each of the following topics. Please note that several topics could be covered in a single workshop. Also note that topics like developing a professional vita will be included in the "Life After the MA" workshop on November 15 $5^{\text {th }}, 5: 30-7: 30 \mathrm{pm}$.

Becoming involved in professional organizations

Conference session proposal writing

- Transforming the Plan A thesis or Plan B capstone project into a professional presentation and/or publication

— Writing in American Psychological Association (APA) style

_ Other: Please explain

It would also be helpful to us if you would provide the following information:

Do you plan to pursue a doctorate at some point in the future? yes no

Are you interested in pursuing a position in a postsecondary institution in one or more of the following roles at some point in the future? Please check all that apply.

Faculty member

Academic support services professional (e.g., academic adviser)

Administrator (e.g., learning center director, multicultural center director)

Other: Please describe 


\section{NOTES}

